\title{
Moving in and out of Financial Distress: Evidence for Newly Founded Service Sector Firms
}

\author{
ULRICH KAISER* \\ Centre for European Economic Research
}

February 2001

\begin{abstract}
The determinants of transitions between different states of financial distress are analyzed using two versions of Markov chain models: a multinomial logit model without random effects and a multinomial logit model capturing such unobservable factors. The empirical analysis is based on a panel data set containing information on 15,538 East German firms founded between 1994 and 1999.

The estimation results indicate that the effect of limited liability depends upon firms' starting state, the existence of corporate shareholders improves firms' financial performance, multiple credit relationships have negative effects and product diversification as well as positive macroeconomic conditions improve firms' financial performance.
\end{abstract}

Keywords: financial distress, Markov chains, multinomial logit model, simulated maximum likelihood, random effects

JEL classification: C15, C33, G33

*Address: Ulrich Kaiser, Centre for European Economic Research, Department of Industrial Economics and International Management, P.O. Box 103443, D-68163 Mannheim, Germany; phone: +49.621.1235.292, fax: +49.621.1235.333, email: kaiser@zew.de internet: http: //www.zew.de/de/mitarbeiter/mitarbeiter.php3?action=mita\&kurz=uka.

I gratefully acknowledge helpful comments from Georg Licht and Andrea Szczesny, from the participants in practioners' workshops at the Center of Finance and Risk Management at University of Mainz, Feb. 16, 2001 and at the ZEW, Mannheim, Oct. 16, 2000, from the participants in a WZB Economics Seminar presentation, Berlin, Nov. 27, 2000 and from the participants in the Applied Economics and Econometrics Brown Bag Seminar at the University of Mannheim, Feb. $7,2001$.

This paper owes much to the ZEW's Mannheim Firm Foundation Panel team - namely Matthias Almus, Dirk Engel, Helmut Fryges and Jürgen Moka — for their ongoing effort to create the data set used in this paper. I wish to express my gratitude to Dirk Engel for patiently sharing his expert knowledge on this data set with me. Lastly, I wish to thank Ruth Dollard for proof-reading. I am indebted to the the German Science Foundation (Deutsche Forschungsgemeinschaft, DFG) for funding this research within the 'Industrial Economics and Input Markets' program under grants PF 331/1-1, 1-2, 1-3 and PO 375/3-1, 3-2, 3-3. 


\section{Non-technical summary}

The recent release of the New Basel Capital Accord on capital adequacy for bank credit assets proposed by the Basel Committee on Banking Supervision (BCBS) has caused the lending policy of European private banks to come under severe reform pressure.

The New Basel Capital Accord will be implemented in member jurisdiction in 2004. It contains far-reaching suggestions to reorganize the equity capitalization of private banks with respect to their lending business. Corporate lending currently requires a blanket coverage of eight percent of the banks' equity, regardless of the riskiness of the credit portfolio. An important new feature of the New Basel Capital Accord in this context is that private banks are allowed to use their own rating systems in order to determine their risk-adequate equity deposit (Internal Ratings-Based Approach). A study of the rating approaches of 30 private banks analyzed by the BCBS in the G-10 member states has, however, revealed that the credit rating approaches of private banks differ markedly from one another, ranging from pure expert systems to systems that rely entirely on statistical methods. Even more importantly, most private banks suffer from a severe lack of credit risk data.

A common solution to the data dilemma is the use of credit rating agency information such as those offered by Germany's largest credit rating agency Creditreform or by the worldwide leading data provider Dun \& Bradstreet. This paper analyzes the determinants of financial distress using a large sample drawn from the Creditreform data base. Since credit rating agency data make it possible to track firms for several years, a dynamic approach to investigating transitions between different states of financial distress is used in this paper.

The main results of the econometric analysis can be summarized as follows: both firm age and firm size significantly affect transition probability. The direction of this effect depends, however, upon the departure state so that no general conclusions can be drawn on this count. Financially non-distressed limited liability firms tend to switch to less desirable financial states more often than unlimited liability entities. Interestingly, given that a firm is already in 'medium' distress, the probability of moving to the no-distress state is significantly larger for limited liability firms than for unlimited liability entities. The existence of corporate shareholders increases the probablity of transition to more favorable financial statuses while just the reverse is true for relationships with multiple creditors. Firm diversification has a significant effect only on the transitions starting from the 'no financial distress' state. The estimation results indicate that diversification increases the likelihood of movements to worse financial states. Finally, a positive macroeconomic development increases the likelihood of transition to better financial situations. 


\section{Introduction}

The lending policy of European private banks has recently come under reform pressure. As a consequence of an increased number of business failures and the associated writing-off of credits in recent years (Creditreform 2000; Dun \& Bradstreet 1998; Wuffli and Hunt 1993), the Basel Committee on Banking Supervision $(B C B S)^{1}$ released the New Basel Capital Accord in January 2001 on capital adequacy for bank credit assets. The Accord contains detailed suggestions for reorganizing the equity capitalization of private banks with respect to their lending business. These suggestions mainly concern corporate lending and will become effective in 2004 when they become, probably with amendments, member jurisdiction and replace the 1988 Basel accord. ${ }^{2}$ Corporate lending currently requires a blanket coverage of eight percent of the banks' equity, independent of the riskiness of the banks' credit portfolio. An important novelty of the New Basel Capital Accord in this context is that private banks are allowed to use their own rating systems in order to determine their risk-adequate equity deposit (Internal Ratings-Based Approach). In a study of 30 private banks in G-10 member states, the BCBS has found that the credit rating approaches of the analyzed private banks markedly differ from one another, ranging from pure expert systems to systems that rely completely on statistical methods. ${ }^{3}$ Although it of course is not quite clear whether statistical methods actually perform better than expert systems, as they did not at leat 30 years ago (Wu 1969); the BCBS finds it desirable that banks' rating systems are based on comparable standards. ${ }^{4}$ Even more important, the BCBS has discovered that there is a severe lack of credit file data, which is the main ingredient of any credit rating system.

But how should private banks construct a rating system without having credit data at hand and without knowing a debtor's credit history? One solution often used by banks — which is also explicitly allowed in the New Basel Capital Accord ${ }^{5}$ — is the use of credit rating agency data such as those of the worldwide operating agency Dun \& Bradstreet and Germany's largest firm information provider Creditreform. ${ }^{6}$ This paper follows the investigates firms' financial situation by analyzing credit rating agency data. A major advantage of such data is that individual firms can be tracked for several years so that movements in and out of financial distress can be studied. A further advantage of credit rating agency data is that firm information is available on almost every firm. Approaches that rely on balance sheet data can, by definition, only be applied if balance sheet data exists at all. Commercial law,

\footnotetext{
${ }^{1}$ The BCBS was founded in 1974 by the $\mathrm{G}-10$ memberstates as an international forum for the coordination of banking supervision.

${ }^{2}$ See the BCBS's website at http://www.bis.org/publ/bcbsca.htm for more details. The special issue of the Journal of Banking \& Finance on 'Credit Ratings and the Proposed New BIS Guidelines on Capital Adequacy for Bank Credit Assets' (2001) deals with the New Basel Capital Accord in great detail. Topics include general comments on the Accord, its effects on portfolio management and its impact on the rating industry.

${ }^{3}$ Treacy and Carey (2000) compare rating systems of the 50 largest U.S. banking organizations and also show that practices differ markedly across the investigated units. Cantor and Packer (1997) refer to differences in rating opinions across rating firms.

${ }^{4}$ For example, Somerville and Taffler (1995) compare formal and expert risk country assessments and conclude that experts tend to be overly pessimistic.

${ }^{5}$ See paragraph 44 of the BCBS document "The Internal Ratings Based Approach" for more details (http: //www. bis .org/publ/bcbsca05.pdf).

${ }^{6}$ Internet information on Dun \& Bradstreet: http://www.dnb.com/, on Creditreform: http: //www. creditreform.de/.
} 
however, usually requires only large firms to publish their balances. ${ }^{7}$

In contrast to many older studies of firms' credit risk which simply investigated the determinants of default, ${ }^{8}$ this paper takes a firms' entire financial distress history into account. For example, it investigates the probability that a firm runs from a (somehow defined) medium distress financial distress situation to a 'no financial problem' or a 'severe financial problem' state.

The appropriate econometric tools to analyze movements between different states of financial distress are Markov chains. Markov chains have been widely applied in studies of default risk (Altman and Kao 1992; Bennett 1984; del Angel et al. 1998; Lawrence et al. 1992; Smith and Lawrence 1995; Nickell et al. 2000) and are the basic ingredient of J.P. Morgan's (1997) CreditMetrics approach. ${ }^{9}$ Following Ngyuen van et al. (2000), the Markov-chain model applied in this paper extends the standard approaches in that it introduces unobserved firm heterogeneity, i.e. it is controlled for firm-specific factors which are not observed by the analyst.

One of the fastest growing sectors of any developed economy is the service sector. Among services, business-related services usually exhibit the highest growth rates (Eurostat 2000). Due to a lack of appropriate data and despite its growing importance, the service sector still is well underresearched both in the credit risk and in the business failure literature. This appears to be a severe shortcoming since firm default and credit default is especially widespread among service sector firms (Creditreform 2000, Phillips and Kirchhoff 1989, May-Strobl and Paulini 1996). This paper therefore adds to the existing literature by its orientation towards the business-related services sector. The focusing on the businessrelated services has the further advantage that sector-specific factors such as business-cycle effects can be properly taken into account by using information from a business survey in the business-related services sector. ${ }^{10}$

A last novel aspect of this paper is that it aims at combining the existing literature on credit risk measurement with that of industrial organization. In their comprehensive survey of credit risk measurement, Altman and Saunders (1998, p. 1724) write that "credit-scoring bankruptcy prediction models are only tenuously linked to an underlying theoretical model". By motivating the factors that drive firms in and out of financial distress by reviewing relevant existing theoretical studies in industrial economics, I try to merge the burgeoning industrial economics literature on firm performance with the literature on financial distress measurement.

This paper defines financial distress in terms of firms' credit repayment mode. Three categories of repayment are considered: (i) a 'no problem' state, where firms receive cash discounts and pay their outstanding debts within agreed limits; (ii) a 'medium problem'

\footnotetext{
${ }^{7}$ For example, German commercial law makes the publication of balances compulsory for firms with: (i) a balance sheet total of more than DM 125 Mio. p.a., (ii) total sales of DM 250 Mio. p.a. and (iii) more than 5,000 employees. Two out of the three criteria have to be fulfilled to make the publication of a balance sheet compulsory, so that only a minor fraction of German firms actually publishes such data.

${ }^{8}$ See the surveys by Altman (1984) Altman and Saunders (1998), Altman and Narayan (1997) and the special issues of the Journal of Banking 65 Finance on 'Company and Country Risk Models' (1984), on 'International Business Failure Prediction Models' (1988) and on 'Credit Risk Assessment and Relationship Lending' (1999) and the references cited therein.

${ }^{9}$ Also see Gordy (2000), who shows that CreditMetrics and Credit Suisse Financial Product's CreditRisk ${ }^{+}$ have similar mathematical structures.

10 Business-related services are defined by the following sectors (Miles 1993): Computers and related activities, Accounting and book-keeping, tax consultancy, Management Consultancy, Architectural activities, Engineering activities, Advertising, Renting of automobiles and transport equipment, Renting of other machinery and equipment, Cargo handling and storage and Sewage and refuse disposal.
} 
state, where firms do not meet their obligations within the agreed time schedule and (iii) a 'severe problem' state, where debt-collection agencies are authorized to collect the outstanding debt or court procedures are started. ${ }^{11}$

The panel data set used in this study consists of 15,538 firms biennially observed from fall 1994 until fall 1999 leading to a total of 90,302 observations. The main results of the econometric analysis are that both firm age and firm size significantly affect the transition probability. The direction of this effect, however, depends upon the starting state so that no general conclusions can be drawn on this count. Financially non-distressed limited liability firms tend to switch to less desirable financial states more often than unlimited liability entities. Given that a firm already is in 'medium' distress, the probability of moving to the no-distress state is significantly larger for limited liability than for unlimited liability firms. The existence of corporate shareholders increases the probablity of transition to more favorable financial statuses while just the reverse is true for relationships with multiple creditors. Firm diversification has a significant effect on the transitions starting from the "no financial distress' state only. The estimation results indicate that diversification increases the likelihood of movements to worse financial states. Finally, positive macroeconomic developments increase the likelihood of transition to better financial situations.

This paper starts with a review of the default risk literature and the firm survival literature in Section 2. Section 3 introduces the data used in this paper. In Section 4, the econometric approach to model transitions between different states of financial distress is described. Estimation results are presented and discussed in Section 5. Section 6 concludes.

\section{Previous studies on firm performance}

The literature on firms' credit risk and on firm survival could basically be labelled "literature on the post-entry performance of firms". Both strands of the literature are concerned with the way firms perform once they have entered the market. The literature on financial distress, however, is concerned with firm performance measured in terms of credit repayment and credit riskiness, usually from a credit analysts' perspective, while the literature on firm survival either takes the view of an economic policy maker or dispassionately describes the forces which drive firms into problems. The explanatory variables included in the estimations for the movements in and out of financial distress are essentially based on models of industry dynamics and explain the effect of firm size and firm age on firm turnover. Other variables involved in the estimation capture firm-organizational aspects such as firms' legal status, their degree of diversification and the presence of corporate shareholders as well as the number of creditors. Finally, they include macroeconomic effects on firm performance.

In the rest of the paper I first motivate the selection of variables included in the estimation by deriving hypotheses from existing theoretical models on firm performance and firm survival. My own empirical results are discussed afterwards in light of these hypotheses and on the background of earlier empirical studies.

\section{Firm age}

In an important contribution to the literature on the evolution of industries, Jovanovic (1982) introduced a market model with noisy selection of entrants. Firms are assumed not to know their own productivity when they enter the market. They observe the productivity of competitors and learn about their own relative productivity in relation to the competitors'

\footnotetext{
${ }^{11}$ Note that this definition compares well to the one given in the New Basel Capital Accord (see paragraph 146 of the BCBS document "The Internal Ratings Based Approach" for more details; (http://www. bis.org/publ/bcbsca05.pdf).
} 
productivity as they continue to stay in the market. Pakes (1998) has shown that many functional specifications of Jovanovics' model imply that it takes time for entrant firms to acquire sufficient information about their productivity parameters before they are able to decide whether to exit or to stay in the market. The instantaneous risk of liquidation thus first increases and then decreases as the entrant firm's beliefs in its own productivity is updated and improved in precision. ${ }^{12}$

This takes us to

Hypothesis 1: Effect of firm age. Firm age has an inverse U-shaped (a U-shaped) effect on the probability of moving into (out of) financial distress.

\section{Firm size}

In the models by Jovanovic and MacDonald (1994) as well as Klepper (1996), innovation is the driving force behind the mobility of firms. Jovanovic and MacDonald (1994) show that major process innovations are challenging to adopt for small firms and hence might force them to exit. Their model is tested using data from the U.S. tire industry and appears to fit reality well. The approach by Klepper (1996) is basically in the same line as that of Jovanovic and MacDonald (1994) and also stresses the superior ability of larger and older firms to adjust to drastic innovations. ${ }^{13}$

Closely related to the ability to adapt to drastic innovations is firms' access to the credit market. Large firms may find it easier to receive external finance since they might be able to pledge more collateral, which implies that firms' size should have a negative effect on the probabilty of moving into financial distress. Organizational geriatics, however, may also evolve from the inflexible organziation of large firms. The larger firms are, the more difficult it is to monitor managers and employees. Intra-firm communication is also more difficult than in small entities. It thus seems plausible that an optimal firm size exists which accounts for the trade-off between organization flexibility and input as well as output market power so Hypothesis 2 states

Hypothesis 2: Effect of firms size. Firm size has an inverse U-shaped (a Ushaped) effect on the probability of moving into (out of) financial distress.

\section{Limited liability}

One of the earliest studies on the effect of limited liability on firm default is Stiglitz and Weiss (1981). ${ }^{14}$ They show that under limited liability, entrepreneurs choose projects characterized by relatively high expected return and a relatively high risk of failure.

Much of the newer literature on the theory of an entrepreneur's choice of legal form is based on transaction cost theory (Gilson 1991; Grundfest 1992; Harhoff et al. 1998; Horvath and Woywode 1997). A limitation of firms' liability entails substantially higher legal fees and taxes compared to the legal form of sole proprietorship. Limited liability firms may also face

\footnotetext{
${ }^{12}$ A model closely related to Jovanovic's (1982) approach is Frank (1988). An extension of the Jovanovic model is presented by Ericsson and Pakes (1995), who introduce active learning.

${ }^{13}$ Additional empirical evidence, again for the U.S. tire industry, is provided in Klepper and Simons (2000).

${ }^{14}$ Stiglitz and Weiss (1981) explain equilibrium credit rationing which has been extensively studied empirically in recent years. Credit restriction in an investment context is reviewed by Hubbard (1999). German evidence on this issue is provided by Elston (1996), Harhoff (1998, for R\&D investment), Plötscher and Rottmann (1998) and Winker (1999). Small and growing firms' access to credit markets is investigated in Egeln et al. (1997, for Germany), Levensohn and Willard (2000), Westhead and Storey (1997), as well as in the survey by Demigüç-Kunt and Maksimovic (1996) and in the special issue of Small Business Economics (1996) on 'Financial Structure and the Growing Small Firm'.
} 
higher cost of capital than unlimited liability firms. The main advantage of limited liability, however, is that it allows entrepreneurs to restrict their personal risk up to the minimum amount required for the foundation of limited liability firms. Hence, limited liability enables entrepreneurs to reduce personal risk at comparatively higher cost imposed by taxation and fees.

A drawback of my study and also of earlier empirical analyses on the effects of limited liability on firm performance is that collaterization is usually not observed in the data. ${ }^{15}$ Harhoff et al. (1998), however, were able to get access to insolvency records of the registration court of a medium-sized German town and conclude (p. 457) "that in Germany banks appear to be particularly successful in attaining full collaterization (...)". Even though full collaterization may be often feasible, from an entrepreneurs' perspective limited liability still is a device to reduce personal risk. Hence, the hypothesis related to the effect of legal status on default risk is:

Hypothesis 3: Effect of limited liability. Limited liability has a positive (negative) effect on the probability that firms move into (out of) financial distress.

\section{Corporate shareholders}

Quite closely related to the discussion of collateralization and default risk is the role of corporate shareholders in the history of firms' credit standings. The shareholding firm has a virtual interest in its investment, hoping that it performs well and does not run into financial distress. Access to external finance is likely to be easier for firms with corporate shareholders than for firms without these investors. Thus, the hypothesis with respect to the effect of corporate shareholders is:

Hypothesis 4: Effect of corporate shareholders. The existence of corporate shareholders has a positive (negative) effect on the probability of moving out of (into) financial distress.

\section{Number of creditors}

Determining the optimal number of firm creditors has only been dealt with in recent years in corporate finance literature. Theoretical contributions tackles this issue in an optimal contracting framework (e.g. Bolton and Scharfstein 1996). In these models, multiple creditors discipline managers from strategic default, i.e. from diverting cash for themselves, since debt renegotiation problems arise in the case of multiple creditors, which reduces mangers' payoff from strategic default. This implies that firms with multiple credit relationships are less likely of moving into financial distress than firms with single credit relationships, leading to

Hypothesis 5: Effect of multiple creditors. Firms with multiple creditors are less likely to run into finanical distress than firms with single creditors and vice versa.

\section{Diversification}

Jovanovic's (1993) model of product diversification choice captures four main reasons to

${ }^{15}$ Much of the literature following Stiglitz and Weiss (1981) focused on the role of collateral on rationing in credit markets with imperfect information. See for example Boot and Thakor (1994), Besanko and Thakor (1987), Bester (1985, 1987, 1994), Broll and Gilroy (1986), Chan and Kanatas (1985), Mattesini (1990), Schmidt-Mohr (1997) and Wette (1983). Empirical studies on the relationship between default risk and collaterization include Berger and Udell (1990), Boot et al. (1991) and, for Germany, Elsas and Krahnen (1999) as well as Ewert et al. (2000). 
diversify: (i) gains in market power: firms with market power in two substitute product fields may be more profitable than two single product monopolies acting noncooperatively; (ii) risk elimination: a diversified product portfolio makes a firm less vulnerable to economic shocks; (iii) access to financial resources: diversified firms may be able to obtain more bargaining power in their banking relations than non-diversified firms; (iv) efficiency gains in production: diversified firms may be able to successfully use complementarities of production factors such as the development of general-purpose technologies. This leads to

Hypothesis 6: Diversification Diversified firms are less (more) likely of moving into (to leave) financial distress than non-diversified firms.

\section{Macroeconomic effects}

That macroeconomic shocks are likely to have a significant effect on firm performance is obvious and does not require theoretical justification. In fact, many empirical studies have found that macroeconomic effects affect firm survival. In this context, Andrade and Kaplan (1998) find significant effects of industry peformance on financial distress. These are, however, dominated by firm-specific factors. Using Belgian data, Sleuwaegen and Dehandschutter (1997) find that domestic GDP growth has a significantly negative effect on firm exit. Audretsch and Mahmood (1995) use U.S. credit rating data and present evidence for significant business cycle effects on firm survival. In a recent study for Japan, Honjo (2000) observes a marked increase in the likelihood of firm exit after the Japanese economy faltered in 1989/1990. In summary, business cycle effects influence movements in and out of financial distress as follows:

Hypothesis 7: Effect of business cycles. A good (bad) overall industry performance increase the likelihood of moving out of (into) financial distress.

\section{Excluded aspects}

Clearly, a lot of variables often used in studies of default risk and firm survival have to be left out here due to data constraints. For example, numerous authors have shown that the human capital endowment of the entrepreneur is an important determinant for firm peformance. These studies include Audretsch and Vivarelli (1993), Bates (1990), Cressy (1995, 1999), Evans and Leighton (1989) Freeman et al. (1983), Hannan and Freeman (1989), Lawrence et al. (1992), Li and Guisinger (1991) and Taylor (1999). German studies include Brüderl et al. (1992), Hinz and Wilsdorf (1999, for eastern Germany) and Prantl (2000). The data set used in this study, however, does not contain reliable information on personal characteristics — just like any study relying on credit rating agency data.

Another crucial issue which has recently gained much attention during the discussion of small business lending and the recent world--wide banking consolidation ${ }^{16}$ is relationship lending. Theoretical contributions on that count include Sharpe (1990) and Wilner (2000), empirical evidence is provided by Berger and Udell (1995), D'Auria et al. (1999), Harhoff and Körting (1998) as well as Petersen and Rajan (1994). ${ }^{17}$ By and large, both the theoretical and the empirical studies show that longstanding lending relationships help to improve the financial conditions of small businesses.

\footnotetext{
${ }^{16}$ See for example Avery et al. (1999), Berger et al. (1998), DeYoung et al. (1999), Jayaratne and Wolken (1999), Strahan and Weston (1996) and the special issues of the Journal of Banking 89 Finance on 'The Consolidation of the Financial Services Industry' (1999) and on 'The Economics of Small Business Finance' (1998).

${ }^{17}$ Also see the special issue of the Journal of Banking \& Finance on 'Credit Risk Assessment and Relationship Lending' (1999).
} 


\section{Data}

The hypotheses listed in Section 2 are tested using data collected by Germany's leading credit rating agency, Creditreform. The data set consists of 15,538 firms or 90,302 observations biennially observed between fall 1994 and fall 1999. Each firm entering the Creditreform database is tracked until the entity is closed so that a balanced panel for each firm is obtained. Firms that emerged from former German Democratic Republic entities, which were privatized, reprivatized or partly privatized by the German privatization agency 'Treuhandanstalt' after German unification in 1990, are removed from the data set. ${ }^{18}$

Empirical analyses based on credit rating data have been subject to various sources of criticisms. A large strand of the literature on firm survival applies data sets based on credit rating agency data (for example Audretsch 1991, 1995; Audretsch and Mahmood 1995; Evans 1987a, 1987b; Harhoff et al. 1998; Li and Guisinger 1991; Phillips and Kirchhoff 1989; Prantl 2000) and has been subject to criticism related to a potential bias of the data sets (Audretsch 1995, Ch. 2.3). It has been argued that small firms are underrepresented in credit rating agency data bases and that there might be a sample selection bias related to legal form. Appendix A refers to such sample selection problems in greater detail by comparing the Creditreform data with information taken from official statistics and concludes that the sample used in this paper is not likely to be affected by sample selection problems. This is rather unsurprising since Creditrefom's core business is to provide up-to-data information on the financial situation of firms to its customers and also acts as a debt collecting agency.

How does this paper define 'financial distress'? The Creditreform database contains detailed information on the mode of payment of the recorded firms. This information is much too detailed to be analyzed in an econometric model so that it is condensed into three main categories: (i) 'no problem', where firms receive a cash discount and pay their outstanding debts within agreements on targets; (ii) 'medium problem', where firms do not meet their obligations within the agreed time schedule and (iii) 'severe problem', where debt collecting agencies are authorized to collect the outstanding debt, the entrepreneur has to declare an affirmation in lieu of an oath, or court composition proceedings or bankruptcy proceedings are started. Table 1 displays observed transition rates between the three states of financial distress. The table shows that the 'no problem' category is most densely populated; 80.5 percent of the firms start in this state. Morevover, only 3.5 of the firms starting with 'no problems' ever leave this state. More variation is present for the 'medium problem' category. 9.8 percent of the firms start in this state, of which 6.7 percent improve their financial condition. The financial situation gets worse, however, for 9.8 percent of the firms. Least variation is found in the 'severe problem' category: 97.5 percent of the firms remain in this state and if they switch at all, they switch to the 'medium problem' category. Since there are very few firms moving from 'severe problem' to any other state both in absolute and relative terms, the last row of the transition matrix is not considered hereafter.

The explanatory variables that are potentially able to explain movements in and out of financial distress as described in Section 2 are firm age and firm size and the variables for limited liability, corporate stockholders, the existence of multiple credit relationships, firm diversification and macroeconomic development are included in the Creditreform data set. Firm size and firm age are both included as their natural logarithms and their squared

\footnotetext{
${ }^{18}$ Written text information is available on almost every firm in the Creditreform data bases. A search engine procedure using the word 'Treuhandanstalt' or similar phrases was run to identify these firms.
} 
Table 1: Transition between the states of financial distress

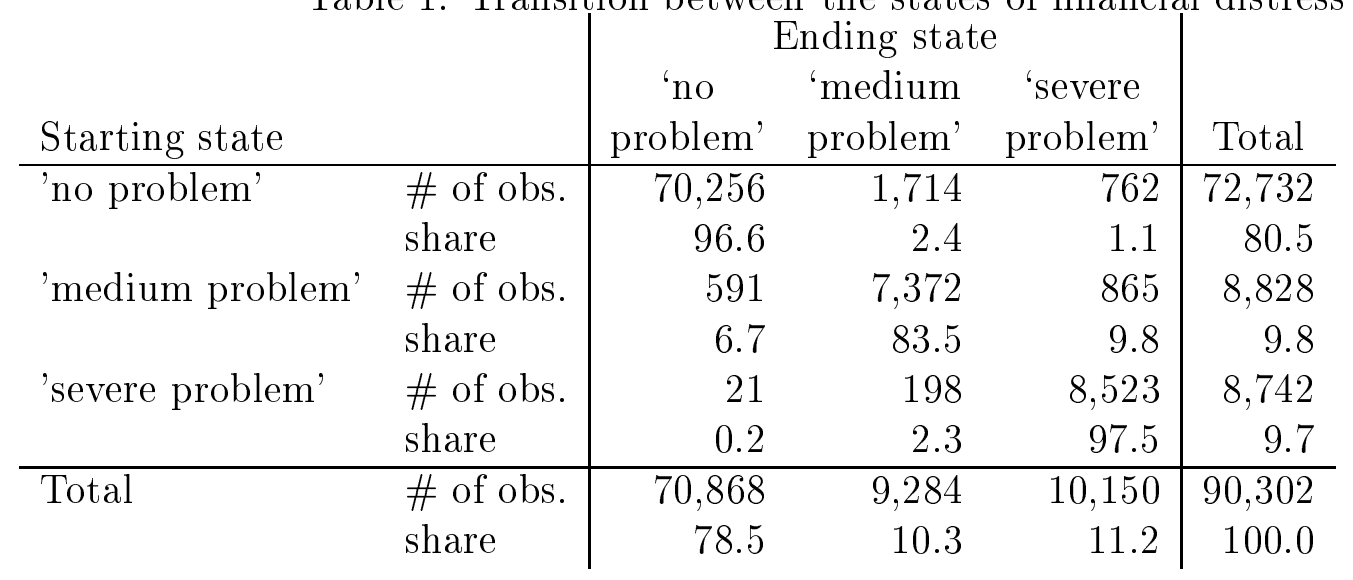

term. The latter variables indicating corporate stockholder, multiple credit relationships and diversification are represented by dummy variables in the econometric specification. Information on macroeconomic fluctuations is taken from another data source: the Service Sector Business Survey (SSBS). The SSBS is a quarterly business survey which is collected by the Centre for European Economic Research in cooperaton with Creditreform since the second quarter of 1994. Details on this data set are presented in Kaiser et al. (2000). It comprises roughly 1,000 firms across the ten sectors listed in Footnote 10 and are repeatedly interviewed quarterly. It is a stratified random sample, stratified with respect to sectoral affiliation, firm size and affiliation to western or eastern Germany. Questions asked in the SSBS include the assessments of the respective firms' sales, price, demand, profit and employment development in the current quarter with respect to the previous quarter. Firms give their assessment on a three point Likert scale.

In this paper, the indicator of macroeconomic fluctuations is firms' assessment of sales changes, since virtually any business survey asks for sales changes whereas few ask for changes in firm profits (CIRET 1998). In order to aggregate firm-level information, balances i.e. the share of firms reporting increased sales minus the share of firms reporting decreased sales, are calculated. ${ }^{19}$ Since economic development markedly differs between East German and West German firms as well as across sectors (Kaiser and Voss 2000), these sales shares are individually calculated for each sector as well as for East Germany. One period-lagged effects of business cycle changes on financial performance is taken into account by including first lags of the sales changes instead of including only the contemporaneous variable.

Appendix B displays descriptive statistics for the variables included in the estimations.

\section{A dynamic model of financial distress}

The transitions between the three different states of financial distress are analyzed using Markov chains. Markov chains are powerful instruments whenever an investigation calls for a dynamic analysis of discrete phenomena. More specifically, the dynamics of financial distress are analyzed by a multinomial logit model that is applied to panel data. The basic idea is to estimate multinomial logit models for each of the three rows of the transition matrix displayed in Table 1.

\footnotetext{
${ }^{19}$ Note that matching the SSBS firms and the firms in my sample is not feasible.
} 
Previous studies such as Nickell et al. (2000) use ordered probit instead of multinomial logit models to analyze Markov chains. Ordered probit models, however, imply that the difference between a transition from e.g. 'no problem' to 'medium problem' is qualitatively the same as the transition from 'medium problem' to 'severe problem'. ${ }^{20}$ This does not, however, appear to be very plausible. Moreover, using an ordered probit model to estimate Markov chain models implies that differentiated effects of particular variables on different transitions cannot be captured. The differences in the implications of the ordered probit and the multinomial logit model are evident: ordered probit models are unable to discriminate between the differentiated effects of individual variables on different transitions.

In this paper, two variants of the multinomial logit model are estimated. The first is the traditional multinomial logit model as implemented in virtually any standard software package. The second variant is a multinomial logit model which takes into account unobserved firm heterogeneity. Both models consider Markov chains of order 1 since Markov chains of higher orders do not seem to be advisable here. Higher orders imply that the financial state in period $t$ depends upon the state in some prior period $t-s$ with $s>1$.

The general model considered here is inspired by Gouriéroux (1989), the extension with unobserved firm heterogeneity borrows from Nguyen et al. (2000).

\section{Model without heterogeneity}

Let $S_{i t}$ denote a variable that indicates the state in which firm $i$ finds itself at time $t$. For example, $S_{i t}=j$ indicates that firm $i$ is in state $j$ at time $t$. The probability of transition of firm $i$ from state $j$ at $t-1$ to state $j^{\prime}$ at $t$ is given given by:

$$
P_{i j j^{\prime}}(t) \equiv P\left(S_{i t}=j^{\prime} \mid S_{i t-1}=j\right)=\frac{\exp \left(\boldsymbol{x}_{\boldsymbol{i t j}} \boldsymbol{\beta}_{\boldsymbol{j} \boldsymbol{j}^{\prime}}\right)}{\sum_{l=1}^{J} \exp \left(\boldsymbol{x}_{\boldsymbol{i t l}} \boldsymbol{\beta}_{\boldsymbol{j l}}\right)},
$$

with $i=1,2, \ldots, N, t=0,1, \ldots, T$ and $j, j^{\prime}=1,2,3$. The observed firm characteristics $\boldsymbol{x}$ are assumed to influence the probability of transition from state $j$ to state $j^{\prime}$ in a way that depends both on $j$ and $j^{\prime}$. For each transition, an individual parameter vector $\beta$ is estimated which linearly relates the vector of observed firm characteristics to the transition probabilities. $^{21}$

After imposing the identification restriction $\boldsymbol{\beta}_{\boldsymbol{j} \mathbf{2}}=0$, the following expressions are obtained: ${ }^{22}$

$$
\begin{aligned}
P_{i j 2}(t) & =\frac{1}{1+\sum_{l \neq 2}^{J} \exp \left(\boldsymbol{x}_{\boldsymbol{i t l}} \boldsymbol{\beta}_{\boldsymbol{j} \boldsymbol{l}}\right)} \\
P_{i j j^{\prime}}(t) & =\frac{\exp \left(\boldsymbol{x}_{\boldsymbol{i t j}} \boldsymbol{\beta}_{\boldsymbol{j} \boldsymbol{j}^{\prime}}\right)}{1+\sum_{l \neq 2}^{J} \exp \left(\boldsymbol{x}_{\boldsymbol{i t l}} \boldsymbol{\beta}_{\boldsymbol{j} \boldsymbol{l}}\right)},
\end{aligned}
$$

with $j=1,2,3, j^{\prime}=1,3$ now. Thus, multinomial logit models for each row of the transition matrix are specified.

Let $n_{i, t-1, t}\left(j j^{\prime}\right)$ denote indicator variables which are coded 1 if firm $i$ has moved from state

${ }^{20}$ The technical difference between ordered probit and multinomial logit models is that the ordered probit model is based on a single index, or a single latent variable, indepent of the number of categories, whereas the multinomal logit model comes with as many indices as categories.

${ }^{21}$ This is in contrast to the ordered probit model where only one, instead of three (or, after normalization, two), parameter vectors are estimated for each row of the transition matrix.

${ }^{22}$ If any vector $\boldsymbol{q}$ is added to the parameter vectors $\boldsymbol{\beta}$, the identical set of probabilities results since all terms including $\boldsymbol{q}$ drop out. Therefore, one of the parameter vectors of each row of the transition matrix needs to be normalized to zero in order to yield unique identification. 
$j$ in $t-1$ to state $j^{\prime}$ at $t$ and 0 otherwise. The log-likelihood function conditional on the state occupied at $t-1$ then is:

$$
\ln L=\sum_{j=1}^{J} \sum_{j^{\prime}=1}^{J} \ln L_{j j^{\prime}} \text {, with } \ln L_{j j^{\prime}}=\sum_{i=1}^{N} \sum_{t=1}^{T} n_{i, t-1, t}\left(j j^{\prime}\right) \ln \left(P_{i j j^{\prime}}(t)\right) \text {. }
$$

Since the quantity $\sum_{j^{\prime}=1}^{J} \ln L_{j j^{\prime}}$ depends upon parameters only, the maximum likelihood estimator can be obtained by separately maximizing the quantities $\sum_{j^{\prime}=1}^{J} \ln L_{j j^{\prime}}$, i.e. by separately maximizing the likelihood functions corresponding to each row of the transition matrix.

\section{Model with unobserved heterogeneity}

In order to account for unobserved heterogeneity, a multinomial logit model with random effects is also specified. These random effects correspond to each firm and each type of transition. In this case, the transition probability is given by:

$$
P_{i j j^{\prime}}(t)=\frac{\exp \left(\boldsymbol{x}_{\boldsymbol{i t j}} \boldsymbol{\beta}_{\boldsymbol{j} \boldsymbol{j}^{\prime}}+\sigma_{j j^{\prime}} u_{i j j^{\prime}}\right)}{\sum_{i=1}^{J} \exp \left(\boldsymbol{x}_{\boldsymbol{i t l}} \boldsymbol{\beta}_{\boldsymbol{j} \boldsymbol{l}}+\sigma_{j l} u_{i j l}\right)},
$$

with $i=1, \ldots N, t=1, \ldots T$ and $j, j^{\prime}=1,2,3$. The terms $\sigma_{j j^{\prime}} u_{i j j^{\prime}}$ are assumed to be mutually independent and independent of $\boldsymbol{x}$, with mean 0 and variance $\sigma_{j j^{\prime}}^{2}$. The random variable $u_{i j j^{\prime}}$ is assumed to be standard normally distributed. After imposing the identifying restriction that $\boldsymbol{\beta}_{\boldsymbol{j} \mathbf{2}}=0$, the following expressions are obtained:

$$
\begin{aligned}
P_{i j 2}(t) & =\frac{1}{1+\sum_{l \neq 2}^{J} \exp \left(\boldsymbol{x}_{\boldsymbol{i t l}} \boldsymbol{\beta}_{\boldsymbol{j} \boldsymbol{l}}+\sigma_{j l} u_{i j l}-\sigma_{j 2} u_{i j 2}\right)} \\
P_{i j^{\prime}}(t) & =\frac{\exp \left(\boldsymbol{x}_{\boldsymbol{i t j}} \boldsymbol{\beta}_{\boldsymbol{j} \boldsymbol{j}^{\prime}}\right)}{1+\sum_{l \neq 2}^{J} \exp \left(\boldsymbol{x}_{\boldsymbol{i t l}} \boldsymbol{\beta}_{\boldsymbol{j} \boldsymbol{l}}+\sigma_{j l} u_{i j l}-\sigma_{j 2} u_{i j 2}\right)},
\end{aligned}
$$

where the parameters $\sigma_{j l}$ have to be estimated. Since the transition probabilities depend upon unoberserved variables, they have to be integrated out in order to compute the likelihood function and to obtain:

$$
E\left(P_{i j j^{\prime}}\right)=\int_{-\infty}^{+\infty} \int_{-\infty}^{+\infty} \int_{-\infty}^{+\infty} P_{i j j^{\prime}}(t) \varphi\left(u_{i j 1}\right) \varphi\left(u_{i j 2}\right) \varphi\left(u_{i j 3}\right) d u_{i j 1} d u_{i j 2} d u_{i j 3}
$$

where $\varphi($.$) denotes the density of the standard normal distribution. E\left(P_{i j j^{\prime}}\right)$ can be approximated using the following simulators:

$$
\begin{aligned}
\hat{E} P_{i j 2} & =\frac{1}{H} \sum_{h=1}^{H} \frac{1}{1+\sum_{l \neq 2}^{J} \exp \left(\boldsymbol{x}_{\boldsymbol{i t l}} \boldsymbol{\beta}_{\boldsymbol{j} \boldsymbol{l}}+\sigma_{j l} u_{i j l h}-\sigma_{j 2} u_{i j 2 h}\right)} \\
\hat{E} P_{i j j^{\prime}} & =\frac{1}{H} \sum_{h=1}^{H} \frac{\exp \left(\boldsymbol{x}_{\boldsymbol{i t j}} \boldsymbol{\beta}_{\boldsymbol{j} \boldsymbol{j}^{\prime}}+\sigma_{j l} u_{i j l h}-\sigma_{j 2} u_{i j 2 h}\right)}{1+\sum_{l \neq 2}^{J} \exp \left(\boldsymbol{x}_{\boldsymbol{i t j}} \boldsymbol{\beta}_{\boldsymbol{j} \boldsymbol{l}}+\sigma_{j l} u_{i j l h}-\sigma_{j 2} u_{i j 2 h}\right)},
\end{aligned}
$$

where the $u_{i j h}$ 's are independent draws from the standard normal distribution. The maximum likelihood estimator for the multinomial logit model with random effects is obtained in the same way as the conventional estimator, i.e. as

$\ln L_{j j^{\prime}}=\sum_{i=1}^{N} \sum_{t=1}^{T} n_{i, t, t-1}\left(j j^{\prime}\right) \ln \left(\hat{E} P_{i j j^{\prime}}\right)$. Separate maximization is feasible in this case as well. 


\section{Estimation results}

The empirical analysis begins by testing if significant random effect are present. This can easily be done by applying a Likelihood Ratio test for the unrestricted model with unobserved heterogeneity against the restricted model without unobserved heterogeneity. The $\chi^{2}$ test-statistic is 2.74 and hence insignificantly different from zero at the usual significance levels ( $p$-value 0.9869). Therefore, the estimation results for the model with unobserved heterogeneity are removed to Appendix C. Due to the insignificant differences between the two models, the interpretation of the estimation results focuses on the findings of the model without unobserved heterogeneity.

In order to ease the interpretation of the estimates, the tables displayed in the main body of the paper do present marginal effects instead of coefficient vectors. Due to the normalization, each coefficient has to be interpreted relative to the base category ('medium problem' in this context). Marginal effects are the percentage changes in the transition from one state to another due to a one unit change in one of the involved variables. For continuous explanatory variables, the effect of a one unit change of the variable $x_{j k}$ on the transition between states $j$ and state $j^{\prime}$ is:

$$
\delta_{j j^{\prime}} \equiv \frac{\partial P_{j j^{\prime}}}{\partial x_{j k}}=P_{j j^{\prime}}\left(\beta_{j j^{\prime} k}-\sum_{l \neq 2}^{3} P_{j l}\right) .
$$

Hence, the effect of a change in the explanatory variable $x_{j k}$ depends on the expression in brackets; the sign of the coefficient $\beta_{j j^{\prime} k}$ does not determine the effect on the probability as opposed to binary choice and ordered choice models. The sign of $\beta_{j j^{\prime} k}$, however, indicates the effect of variable $x_{k}$ on the corresponding choice relative to the base category 'medium problems'. Marginal effects are usually calculated at the means of the involved variables, and I proceed the same way in this paper. The variance-covariance matrix for the marginal effects is calculated using the 'Delta-method' (e.g. Greene 1997, Sec. 6.7.5). The original estimation results are displayed in Appendix D.

For the dummy variables, the percentage change associated with a switch from 0 to 1 instead of the marginal effect as in equation (11) is calculated. Standard errors for the marginal effects corresponding to the dummy variables are calculated using the 'Delta'-method as well.

The empirical analysis starts with the identification of the variables leading to transitions from the 'no problem' to one of the other three states, i.e. it is concerned with the first row of the transition matrix. Table 2 displays estimates of the marginal effects of the variables motivated in Section 2 and for the transitions starting from 'no problem'. Marginal effects for the transitions starting from 'medium problem' are shown in Table 3.

\section{Firm age}

The results for firm age are only partly consistent with the predictions of Hypothesis 1 . For the transition from 'no problem' to 'medium problem', an inverse U-shaped and jointly significant effect is found. An inverse U-shaped and jointly significant effect on the probability of moving into financial distress — as predicted by Hypothesis 1 - is also found for the transition from 'medium problem' to 'severe problem'. For both transitions, the effect increases over the firm ages found in the sample. In contradiction to Hypothesis 1, a U-shaped and jointly significant effect of firm age is found for the transition from 'no problem' to 'severe problem'; the minimum is reached at an age of 1.2 years. 
Table 2: Marginal effects (in percent) for transition from 'no problem'

Transition from...

\begin{tabular}{|c|c|c|c|c|c|c|}
\hline & \multicolumn{2}{|c|}{ 'no' to 'no' } & \multicolumn{2}{|c|}{ 'no' to 'med.' } & \multicolumn{2}{|c|}{ 'no' to 'severe' } \\
\hline & M. eff. & Std. err. & M. eff. & Std. err. & M. eff. & Std. err. \\
\hline $\ln ($ age $)$ & $-1.0330^{* * *}$ & 0.3112 & $1.0787^{* * *}$ & 0.2724 & -0.0457 & 0.1664 \\
\hline $\ln (\text { age })^{2}$ & -0.0213 & 0.1549 & -0.1033 & 0.1318 & $0.1246^{*}$ & 0.0839 \\
\hline $\ln (\#$ of employees $)$ & $-0.5338^{*}$ & 0.3516 & $0.4326^{*}$ & 0.2893 & 0.1013 & 0.2046 \\
\hline $\ln (\# \text { of employees })^{2}$ & 0.0444 & 0.0882 & 0.0063 & 0.0718 & -0.0507 & 0.0522 \\
\hline Limited liability & $-0.7246^{* * *}$ & 0.1659 & 0.0145 & 0.1196 & $0.7101^{* * *}$ & 0.1174 \\
\hline Corp. Shareholders & $0.3055^{*}$ & 0.2099 & $-0.2986^{* *}$ & 0.1779 & -0.0069 & 0.1132 \\
\hline Multiple creditors & $0.6104^{* * *}$ & 0.2101 & $-0.4139^{* * *}$ & 0.1784 & $-0.1965^{* *}$ & 0.1125 \\
\hline Diversification & $-0.2623^{* *}$ & 0.1555 & -0.0084 & 0.1258 & $0.2706^{* * *}$ & 0.0932 \\
\hline Sales index/100 & $0.0078^{* * *}$ & 0.0030 & -0.0028 & 0.0025 & $-0.0050^{* * *}$ & 0.0017 \\
\hline
\end{tabular}

Note: 'M. eff.' denotes marginal effects. The estimation included a total of 68,229 observation. See Appendix D for the coefficient estimates.

U-shaped effects of firm age on movements out of financial distress as predicted by Hypothesis 1 are not supported by the empirical results: firm age has a uniquely negative effect on remaining in the 'no problem' state. It does not have a significant effect on the transition from 'medium problem' to 'no problem' and has a U-shaped effect on the probability of remaining in the 'medium problem' state; the minimum is reached at an age of 5.2 years. The very differentiated effects of firm size on the various transition probabilities highlights a major advantage of the multinomial logit model over the more restricted ordered probit model as applied by Nickell et al. (2000): if an ordered probit model was used for estimating the transition probabilities starting from 'medium problem', e.g. uniquely negative (positive) effect would have been found for the probability of moving from 'medium problem' to 'no problem' and for the probability of remaining in 'medium problem' (on the probability to switch from 'medium problem' to 'severe problem').

Earlier empirical studies which focus on the binary outcome firm exit/firm survival and which do not consider more differentiated types of firm performance, as my investigation does, mostly support Hypothesis 1 and find evidence for first increasing and then decreasing hazard rates of firm exit, as noted in the survey by Caves (1998, Section 2.3). ${ }^{23}$ More recent studies for Germany that come to the same conclusion include Harhoff et al. (1998) and Prantl (2000).

These studies and some of my results contradict Agarwal and Gort's (1996) model of 'organizational geriatics' which implies first decreasing and then increasing hazard rates. They regard the survival of firms as a trade-off between depreciation and obsolescence of their initial human and physical capital endowment and the benefits of cumulative learning. Their empirical analysis allows them to calculate 'senility points', firm ages at which hazard rates stop declining and turn up again.

\section{Firm size}

An inverse U-shaped effect of firm size on the probability of moving into financial distress as predicted by Hypothesis 2 is found for the transition from 'no problem' to 'severe problem'

\footnotetext{
${ }^{23}$ One exception is the constantly increasing hazard rate of small Belgian firms found in Konings et al. (1996).
} 
Table 3: Marginal effects for transition from 'medium problem'

Transition from...

\begin{tabular}{|c|c|c|c|c|c|c|}
\hline & \multicolumn{2}{|c|}{ 'med.' to 'no' } & \multicolumn{2}{|c|}{ 'med.' to 'med.' } & \multicolumn{2}{|c|}{ 'med.' to 'severe' } \\
\hline & M. eff. & Std. err. & M. eff. & Std. err. & M. eff. & Std. err. \\
\hline $\ln ($ age $)$ & 0.9002 & 1.2104 & $-3.9325^{* * *}$ & 1.8873 & $3.0323^{* *}$ & 1.5688 \\
\hline $\ln (\text { age })^{2}$ & -0.6818 & 0.6338 & 1.1863 & 0.9565 & -0.5045 & 0.7727 \\
\hline $\ln (\#$ of employees $)$ & $4.5705^{* * *}$ & 1.4445 & $-5.4563^{* * *}$ & 2.1167 & 0.8858 & 1.7166 \\
\hline $\ln (\# \text { of employees })^{2}$ & $-0.7939^{* * *}$ & 0.3467 & $0.8688^{* *}$ & 0.5302 & -0.0750 & 0.4359 \\
\hline Limited liability & $1.7502^{* * *}$ & 0.6366 & $-2.5974^{* * *}$ & 0.9099 & 0.8472 & 0.7151 \\
\hline Corp. Shareholders & $2.7083^{* *}$ & 1.3025 & $-3.1099^{* *}$ & 1.8498 & 0.4016 & 1.4338 \\
\hline Multiple creditors & $2.4324^{* * *}$ & 1.0645 & 0.2546 & 1.3701 & $-2.6870^{* * *}$ & 0.9521 \\
\hline Diversification & 0.2276 & 0.5900 & -0.5089 & 0.9085 & 0.2813 & 0.7402 \\
\hline Sales index/100 & -0.0125 & 0.0119 & $0.0525^{* * *}$ & 0.0187 & $-0.0399^{* * *}$ & 0.0155 \\
\hline
\end{tabular}

Note: 'M. eff.' denotes marginal effects. The estimation included a total of 8,402 observation. See Appendix D for the coefficient estimates.

(the maximum is reached at a firm size of 2.7 employees) and from 'medium problem' to 'severe problem' (where the maximum is not reached for the firm sizes found in the sample). The latter effect, however, is not significantly different from zero. A U-shaped effect of firm size on movements out of financial distress as predicted by Hypothesis 2 is not supported by the estimation results: the impact of firm size on the transition from 'medium problem' to 'no problem' is inverse U-shaped (with a maximum at 17.8 employees). The effect of firm size on the transition from 'no problem' to 'medium problem' is uniquely positive. U-shaped effects of firm size are present for the probability of remaining in the 'no problem' state and also for the probability of staying in the 'medium problem' state.

Existing studies such as Harhoff et al. (1998) and Mata (1994) find that firm size has a negative impact on the probability to exit and hence contradict the prediction of Hypothesis 2. Empirical support for Hypothesis 2 is provided by Prantl (2000), who concludes that the effect of firm size on hazard rates is inverse U-shaped for bankruptcy as a means of exit.

\section{Limited liability}

Consistent with Hypothesis 3, limited liability has a positive and significant effect on the transition from 'no problem' to 'severe problem': the probability that limited liability firms move from 'no problem' to 'severe problem' is 0.7 percentage points larger than for firms without limited liability. The effect on the probability of remaining in one of the starting states is negatively affected. Somewhat surprisingly, the effect of limited liability on the transition from 'medium problem' to 'no problem' is highly significantly positive. This implies that, given that a firm has encountered financial pressure, the shareholders of the limited liability firm have incentives to restructure firm debt.

The empirical results of this paper concerning the effect of limited liability on firm performance are in broad accordance with earlier studies. In empirical studies using data sets very comparable to the one used in this paper, Harhoff and Stahl (1995), Harhoff et al. (1998) and Prantl (2000) find negative effects of limited liability on firm survival and hence also support Hypothesis 3.

\section{Corporate shareholders}


The existence of corporate shareholders has a significantly positive effect on the transition from 'medium problem' to 'no problem' which is consistent with Hypothesis 4. Also in keeping with Hypothesis 4, the impact of corporate shareholders is negative for the transition from 'no problem' to 'medium problem'. A positive and weakly significant effect is found for the probability of remaining in the 'no problem' state, a significantly negative effect is found for remaining in the 'medium problem' state.

Empirical evidence on the effect of the existence of corporate shreholders on firm performance is scarce. In an investigation of U.S. firms, Sharma (1998) finds that relatedness with foreign parent firms has a negative effect on aquisitive firm exit supporting Hypothesis 4 . For Germany, Harhoff and Stahl (1995) do not find significant effects of corporate ownership on firm exit.

\section{Multiple credit relationships}

The empirical results for the dummy variable for multiple credit relationships are perfectly consistent with Hypothesis 5: firms with more than just one creditor are less likely of moving into worse states while the opposite holds for firms with single creditors.

Comparable empirical results are presented by Harhoff and Körting (1998) who use German survey data to show that financially distressed firms tend to be involved in multiple lending relationships while firms in a good financial condition tend to rely on single borrowers.

\section{Diversification}

Diversification has significant effects on the transitions starting from the 'no problem' state. It has a significantly positive effect on the transition to the 'severe problem' state and a significantly negative impact on the probability of remaining in the 'no problem' category. Hence, Hypothesis 6 is partially supported empirically.

Empirical evidence of the effect of diversification on financial performance is scarce as well. For a large sample of US firms, Berger and Ofek (1995) find that diversification is at the origin of the decline of the firm performance. It reduces firm profitability and firm value. Lang and Stulz (1994) show that diversification has had a negative effect on Tobin's $q$ for American firms during the 1980s and that the $q$ of diversified firms is smaller than that of the non-diversified firms. These results are consistent with the idea of Aw and Batra (1998) who argue that firm diversification might be a manager's device to gain prestige. It further enables managers to decrease the precision of information transmitted to shareholders. Diversification also goes along with transaction costs. Studies for Germany, however, such as that by Harhoff et al. (1998) and Prantl (2000), do not find significant effects of firm diversification.

\section{Macroeconomic effects}

Improvements in the economic environment have the expected positive and significant effect on the transitions to states with improved financial status as expected from Hypothesis 7 . The inverse effect is present for transitions to weaker financial health statuses. Exceptions are the transition from 'no problem' to 'medium problem' and from 'medium problem' to 'no problem' where the effects are insignificant.

Now that the coefficients of the explanatory variables are estimated, it is easy to derive individual firm-specific transition probabilities. If the transition probability of a firm has to be calculated, the credit analyst simply has to plug in the characteristics of this firm into expressions (2) and (3). For a 2 year old firms with 10 employees, limited liability, corporate shareholders, more than one creditor, which is diversified and for a sales index of 20 
percent for the firm's sector, the probabilities of moving from 'medium problem' to 'no problem'/'medium problem'/'severe problem' are: 18.4/74.2/7.3 percent respectively. To compare, the transition probabilities for the same firm with unlimited liability are 14.3/78.8/6.9 percent respectively.

Table 4 displays the mean estimated transition probabilities and compares them with actual transition probabilities. The implied transition probabilities are estimated with high precision; each of them is highly significant from zero. Estimated and actual transition probabilities compare very well, which indicates that the model suggested here is well suited for practical purposes.

Table 4: Estimated and actual transition probabilities

\begin{tabular}{|c|c|c|c|c|}
\hline \multirow{2}{*}{\multicolumn{2}{|c|}{ Starting state }} & \multicolumn{3}{|c|}{ Ending state } \\
\hline & & $\begin{array}{c}\text { 'no } \\
\text { problem' }\end{array}$ & $\begin{array}{l}\text { 'medium } \\
\text { problem' }\end{array}$ & $\begin{array}{c}\text { 'severe } \\
\text { problem' }\end{array}$ \\
\hline \multirow[t]{2}{*}{ 'no problem' } & estimated & 96.7 & 2.2 & 1.0 \\
\hline & actual & 96.6 & 2.4 & 1.1 \\
\hline \multirow[t]{2}{*}{ 'medium problem' } & estimated & 6.4 & 84.1 & 9.5 \\
\hline & actual & 6.7 & 83.5 & 9.8 \\
\hline
\end{tabular}

\section{Diagnostics and goodness-of-fit measures}

The Multinomial Logit Model imposes the assumption of "Independence of Irrelevant Alternatives" (IIA) which states that the probability ratio of any two transition-probabilities does not depend on the presence of other transition possibilities. If a subset of the choice set truly is irrelevant, omitting it from the model does not change the parameter estimates systematically; if the subset is not irrelevant, the parameter estimates obtained when the choice subset is omitted are inconsistent. The IIA assumtion can be tested using the Hausman and McFadden (1984) test which is given by:

$$
\varepsilon^{H}=\left(\hat{\boldsymbol{\theta}}_{\boldsymbol{u}}-\hat{\boldsymbol{\theta}}_{\boldsymbol{r}}\right)^{\prime}\left[\boldsymbol{V}\left(\hat{\boldsymbol{\theta}}_{\boldsymbol{u}}\right)-\boldsymbol{V}\left(\hat{\boldsymbol{\theta}}_{\boldsymbol{r}}\right)\right]^{-1}\left(\hat{\boldsymbol{\theta}}_{\boldsymbol{u}}-\hat{\boldsymbol{\theta}}_{\boldsymbol{r}}\right) .
$$

The test statistic is $\chi^{2}$ distributed with degrees of freedom equal to the rank of the matrix $\boldsymbol{V}\left(\hat{\boldsymbol{\theta}}_{\boldsymbol{u}}\right)-\boldsymbol{V}\left(\hat{\boldsymbol{\theta}}_{\boldsymbol{r}}\right)$. Since this matrix has not always been positively semidefinite, it is proceeded along the lines of Small and Hsiao (1985). IIA cannot be rejected at the usual significance levels for any of the specifications. Table 5 displays the test statistics and the associated $p$-values.

A common property of any discrete choice model is that they always predict those states best that are most densely populated. It is therefore rather surprising that 96.7 percent of the actual outcomes for the transitions from the 'no problem' state are correctly predicted. For the transition from the 'medium problem' state, the related figure is 84.1 percent. McFadden's (1979) prediction success index for the transition from the 'no problem' state is 0.03 and hence is quite modest, due to the dense population of the no-change state and the narrow population of the other states. The prediction success index for the transitions starting in the 'medium problem' state is 0.12 percent and convenient for those kinds of models. 
Table 5: Test of IIA ( $p$-values in parentheses)

\begin{tabular}{l|ccc} 
Departure state & \multicolumn{3}{|c}{$\begin{array}{c}\text { Left-out state } \\
\end{array}$} \\
\hline 'no problem' & - & 9.3214 & 5.7542 \\
& & $(0.5019)$ & $(0.8354)$ \\
'medium problem' & $\begin{array}{l}7.1467 \\
(0.7115)\end{array}$ & - & 11.1524 \\
& & & $(0.3458)$
\end{tabular}

\section{Conclusions}

The new Bank of International Settlements 'Guidelines on Capital Adequacy for Bank Credit Assets' have put severe reform pressure on private bank's corporate lending. One of the most important novelties associated with the New Basel Capital Approach is that banks will be allowed to used internal credit ratings in order to determine the risk weights associated with a particular credit. Such an internal rating system appears to be difficult to implement for many private banks for a very obvious reason: many private banks do not systematically record their debtor's performance. In order to overcome this deficit of data, it seems likely that private banks will use data provided by credit rating agencies to obtain information on individual debtors and to determine the riskiness of starting or pursuing a credit relationship. In this paper, a simple method to estimate the credit risk of firms', as one particularly important group of debtors, is suggested and implemented using data taken from Germany's leading credit rating agency.

The paper begins by reviewing and integrating existing theoretical and empirical contributions to the credit risk and to the firm survival literature in order to condense variables which help to explain firms' movements in and out of financial distress. Seven variables are identified this way: firm age, firm size, legal form, the existence of corporate shareholders, the existence of multiple creditors, the degree of firm diversification and macroeconomic effects.

Financial distress is defined by a firm's mode of credit repayment. If credits are repaid within the agreed time limit, these firms are defined as being unaffected by financial distress. If they are unable to meet their obligations punctually, they are said to encounter 'medium financial problems'. If court procedures are started, those firms are regarded as having 'severe' financial distress.

In order to account for the history of firms' financial status, Markov chain models are estimated on a panel data set of newly founded eastern German firms from the business-related services sector. The data set comprises 15,538 firms observed biennially from fall 1994 until fall 1999 and amounts to a total of 90,302 observations. Multinomial logit models are used to examine the driving forces behind movements in and out of financial distress. Two variants of this model are estimated: the well known multinomial logit model and a multinomial logit model that captures random effects.

The main results of the econometric analysis can be summarized as follows: both firm age and firm size significantly affect transition probabilities. The direction of this effect, however, depends upon the starting state so that no general conclusions can be drawn on this count. Financially non-distressed limited liability firms tend to switch to less desirable financial states more often than unlimited liability entities. Interestingly, given that a firm is already in 'medium' distress, the probability of moving to the no-distress state is 
significantly larger for limited liability than for unlimited liability firms. The existence of corporate shareholders increases the probablity of transition to a more favorable financial status while just the reverse is true for relationships with multiple creditors. Firm diversification only has a significant effect on transitions starting from the 'no financial distress' state. The estimation results indicate that diversification increases the likelihood of movements to worse financial states. Finally, a positive macroeconomic development increases the likelihood of transition to better financial situations.

This paper of course is just the first step in the development of an internal credit rating system. The methodology and the data used here seem to be well suited to the analysis of small and newly founded firms' credit risk. The construction of a complete credit rating system is, however, beyond the scope of this paper and is left for further research. 


\section{Appendix A: Data description}

The data set used in this study was provided to the ZEW by Germany's largest credit rating agency, Creditreform. Creditreform aims at collecting information on each and every firm located in Austria, Germany and Switzerland. The German data are collected by 134 region-specific bureaus of Creditreform ('Vereine Creditreform') in a standardized way (see Stahl 1991 for details). The individual branches of Creditreform are organized in a franchising-system within the 'Verband der Vereine Creditreform' (Creditreform association). Creditreform's core business is to deliver information on the credit worthiness of firms to Creditreform member firms. These information is requested in order to avoid starting a business with an illiquid firm for example. Other branches of Creditreform's business are the collection of bills and the provision of marketing information.

Firms typically enter the Creditreform database for two reasons: (i) Creditreform proactively updates its database by using publicly available information such as the 'Handelsregister' (trade register to registration is compulsory for all incorporated firms), news and magazines as well as company and balance-sheet reports and/or (ii) a customer or supplier requests information on a prospective business partner. Information recorded in the initial data entry include the ownership structure, the primary and secondary five digit industry classification, the legal form, the current number of employees, current sales, the firm foundation date and the foundation date of predessor firms. This information is usually taken from interview examinations by the Creditreform staff and/or from publicly available data resources and/or (Stahl 1991). In order to be able to track firms, Creditreform attaches a firm identifier to each entity recorded in the database. This identifier unfortunately is not always unique. Multiple entries of single firms can occur if (i) a firm relocates geographically and hence moves from one Creditreform bureau to another, (ii) a merger of firms via a firm foundation takes places and (iii) an existing firm is split up via a firm foundation. In order to remove multiple entries from the sample, I proceed along the lines of Almus et al. (2000, Section 3.2.2) who exclude multiple entries by using a search engine procedure based on written text information corresponding to each firm recorded by Creditreform.

Creditreform started to transfer data referring to newly founded West German firms (often referred to as the 'ZEW Firm Foundation Panel West') in May 1990. Since September 1991, the ZEW has also received the entire database related to East Germany (called the 'ZEW Firm Foundation Panel East', although this database also includes incumbent firms). Both data sets are regularly updated twice a year. The ZEW then receives the information corresponding to each firm for which information had been delivered in the past plus the information on firms which have recently entered the Creditreform database.

Creditreform is unable to instantaneously record each and every newly founded firm. This is not surprising since the number of firm foundations is large: according to the Federal Statistical Office (Statistisches Bundesamt 2000), a total of 174,018 firms were newly founded in Germany in 1998. Consequently, Creditreform did not transfer information on these newly founded but not yet recorded firms to the ZEW. Hence, the older waves of the ZEW firm foundation panel West missed a considerable number of observations. This problem has recently been overcome since Creditreform changed its data format and now delivers information on firms founded and recorded between two successive data deliveries as well as on firms which were recorded after the respective last data delivery. Such a problem is not present in the East German Firm Foundation Panel since the ZEW receives information on all of the East German firms recorded by Creditreform.

As Harhoff et al. (1996 and, in less detail, 1998) have pointed out, the data collection habits of Creditreform differ from academic standards. A first difference is that Creditreform acts 
in a demand-driven manner. This implies that firms tend to enter the database and/or are updated if there is demand for information on the respective type of firms. Hence, two sources of sampling (not necessarily selection) bias are likely to be present in the Creditreform data. The first refers to firms size. Information on large firms is likely to be requested more than information on small firms since large firms are more engaged in relationships to multiple suppliers and customers in general than small firms. In a comparison of Creditreform data with data taken from official sources, Licht and Stahl (1994) demonstrate that the Creditreform data cover virtually all firms with more than five employees. The data coverage of Creditreform has, however, markedly improved since 1994 as Almus et al. (2000) note.

In order to check whether there is an oversampling of large firms and an undersampling of small firms, I compare the share of firms in eleven sales size classes (in million German Marks) listed below with the Sales Tax Statistic compiled by the official statistics. The official source of information on tax consultancy, architecture and engineering is Federal Statistical Office (Statistisches Bundesamt 1998a), for transport it is Statistisches Bundesamt (1998b), for management consultancy and software it is Statistisches Bundesamt (1997). The data refer to 1995, 1995, and 1994, respectively and also correspond to East Germany. The firm shares as displayed in the table below refer to these years accordingly.

It is important to note that the official statistic and the Firm Foundation Panel East data cannot be readily compared since they correspond to all fims in the business-related service sector instead of to newly founded firms only. The lack of data provision on newly founded firms, however, hampers any direct comparison so that the figures displayed and compared in the table below give at least some guidance on whether or not there is a firm size bias in the Firm Foundation Panel East.

\begin{tabular}{|c|c|c|c|c|c|c|}
\hline & \multicolumn{2}{|c|}{ Tax cons. } & \multicolumn{2}{|c|}{ Arc. \& eng. } & Transport & $\begin{array}{l}\text { Sport } \\
\text { Sample }\end{array}$ \\
\hline $25,000-50,000$ & 2.0 & 0.4 & 3.9 & 0.2 & & \\
\hline $50,000-250,000$ & 29.5 & 30.5 & 58.6 & 14.2 & 17.6 & 18.2 \\
\hline $250,000-500,000$ & 28.1 & 25.3 & 17.9 & 18.4 & 14.7 & 15.5 \\
\hline 500,000-1 Mio. & 27.2 & 26.5 & 11.3 & 29.1 & 26.5 & 24.3 \\
\hline 1 Mio.-2 Mio. & 9.1 & 9.8 & 5.8 & 22.4 & 21.1 & 19.9 \\
\hline \multirow[t]{3}{*}{$>2$ Mio. } & 4.1 & 7.5 & 2.5 & 15.8 & 20.9 & 22.1 \\
\hline & \multicolumn{4}{|c|}{ Software } & & \\
\hline & Official & Sample & Official & Sample & & \\
\hline $25,000-50,000$ & & 0.1 & & 0.2 & & \\
\hline $50,000-250,000$ & 35.4 & 20.1 & & 20.6 & & \\
\hline $250,000-500,000$ & 25.0 & 16.2 & 28.1 & 26.7 & & \\
\hline 500,000-1 Mio. & 18.8 & 26.5 & 32.4 & 24.9 & & \\
\hline 1 Mio.-2 Mio. & 14.6 & 24.4 & 27.0 & 18.1 & & \\
\hline$>2$ Mio. & 6.3 & 12.6 & 12.5 & 9.5 & & \\
\hline
\end{tabular}

The table indicates minor deviations for tax consultancy and transport. Medium deviations are present for management consultancy and software while there are some sharp differences for architecture and engineering, where a large number of free-lancers is present.

The second potential sampling bias refers to firms' legal forms since, as Licht and Stahl (1994) have demonstrated, the Creditreform database includes information on almost all firms filed in the trade register. It is therefore to be expected that limited liability firms 
should be overrepresented in the Creditreform data while the reverse is true for small sole proprietorship firms. A comparison of the data used in this paper with the Sales Tax Statistic (Statistisches Bundesamt 1998c) only partially supports this initial guess: while the legal forms general commercial partnership ('Offene Handelsgesellschaft - OHG'), Limited commercial partnership ('Kommanditgesellschaft — KG'), stock corporation and 'other' appear to be correctly represented, an overcoverage of limited liability firms and an undercoverage of sole proprietorship firms is found:

\begin{tabular}{l|cc|c} 
Legal form & Official & Sample & diff. \\
\hline $\begin{array}{l}\text { Sole proprietorship } \\
\text { ('Einzelunternehmen') }\end{array}$ & 73.5 & 42.5 & 31.0 \\
General commercial partnership & 7.8 & 11.2 & -3.4 \\
('Offene Handelsgesellschaft - OHG') & & & \\
Limited commercial partnership & 1.3 & 1.3 & 0.0 \\
('Kommanditgesellschaft - KG') & & & \\
Stock corporation & 0.0 & 0.0 & 0.0 \\
Limited Liability corporation & 16.9 & 44.6 & -27.8 \\
Other legal forms & 0.2 & 0.4 & -0.1
\end{tabular}

It has to, however, be kept in mind that the figures taken from the official statistics refer to all of Germany and not only to East Germany. Moreover, the figures are related to all firms in Germany and not only to newly founded firms.

Is the oversampling of large firms and of firms with limited liability likely to lead to a $s e$ lection bias in the present context? Selection bias arises whenever the probability of the inclusion of a particular observation in the sample depends upon the phenomenon to be analyzed. In the present context, the question to be answered is whether the probability of Creditreform recording a firm depends upon the firm's financial distress situation. This in turn would only be the case if firms requesting information knew in advance that the firm it wishes to do business with is in financial distress. But if this is true, why should the Creditreform customer submit a costly request to the credit agency? This view is supported by the Firm Foundation Panel data: 89 percent - and hence ten percentage points more than in the overall sample - are not financially distressed when they enter the database. Nine percent have intermediate problems and three percent have to cope with severe problems. In conclusion, firm size and legal status do not appear to lead to a selection bias in the estimates.

Another source, and at least potentially a more severe source, of selection bias is the irregular updating of firm information. As a profit-maximizing firm, Creditreform tends to proactively update information on firms for which it expects customer requests in the near future i.e. without the current presence of customer requests. This source of selection bias has been thoroughly discussed by Harhoff et al. (1996, 1998). Harhoff et al. were able to control for potential selection bias in their firm growth and survival estimates by conducting telephone interviews with those firms that have not been updated regularly. With regard to the sample size present here, such a procedure is rendered impossible. However, with respect to the subject of analysis, the situation is markedly different compared to the study by Harhoff et al. To see that, recall that Creditreform's main business is to provide its customers with information on the financial status of a prospective business partner and also acts as a debt collecting agency. Therefore, Creditreform is eager to proactively become aware of changes in firms' financial statuses so that it seems likely that a selection bias as described by Harhoff et al. $(1996,1998)$ is not present here. If this view is 
correct, then the population of the three 'no-change' categories (firms remain in the 'no problem'/'intermediate problem'/'severe problem' category) should remain the same independent of the number of updates having occured over time. A comparison of the transition matrices corresponding to (i) all firms in the sample and (ii) to firms that have been updated at least five times confirms the initial guess: the population of the 'no-change'-states remains remarkably stable regardless of the number of updates (also compare Table 1 in the text):

\begin{tabular}{l|cc|c} 
& $\begin{array}{c}1 \text { up- } \\
\text { date only }\end{array}$ & $\begin{array}{c}\text { more than } \\
5 \text { updates }\end{array}$ & diff. \\
\hline remaining in 'no problem' & 95.6 & 94.7 & 0.9 \\
remaining in 'mid problem' & 79.0 & 79.5 & -0.5 \\
remaining in 'severe problem' & 96.3 & 94.1 & 2.3
\end{tabular}




\section{Appendix B: Descriptive statistics}

\begin{tabular}{|c|c|c|c|c|}
\hline & \# of obs. & Mean/share & Std. dev. & Median \\
\hline \multicolumn{5}{|c|}{ "Starting state: 'no problem' } \\
\hline $\ln ($ age $)$ & 68,229 & 0.9067 & 0.6789 & 1.0986 \\
\hline $\ln (\text { age })^{2}$ & 68,229 & 1.2830 & 1.2855 & 1.2069 \\
\hline $\ln (\#$ of employees $)$ & 68,229 & 1.6097 & 0.7737 & 1.3863 \\
\hline $\ln (\# \text { of employees })^{2}$ & 68,229 & 3.1898 & 3.0017 & 1.9218 \\
\hline Limited liability & 68,229 & 0.4981 & & \\
\hline Corp. Shareholders & 68,229 & 0.0864 & & \\
\hline Multiple creditors & 68,229 & 0.0780 & & \\
\hline Diversification & 68,229 & 0.2484 & & \\
\hline Sales index/100 & 68,229 & -1.6477 & 20.8330 & -6.2500 \\
\hline \multicolumn{5}{|c|}{ Starting state: 'medium problem' } \\
\hline $\ln ($ age $)$ & 8,402 & 0.9721 & 0.6787 & 1.0986 \\
\hline $\ln (\text { age })^{2}$ & 8,402 & 1.4054 & 1.3213 & 1.2069 \\
\hline $\ln (\#$ of employees $)$ & 8,402 & 1.5771 & 0.7970 & 1.3863 \\
\hline $\ln (\# \text { of employees })^{2}$ & 8,402 & 3.1225 & 3.1131 & 1.9218 \\
\hline Limited liability & 8,402 & 0.4843 & & \\
\hline Corp. Shareholders & 8,402 & 0.0536 & & \\
\hline Multiple creditors & 8,402 & 0.0884 & & \\
\hline Diversification & 8,402 & 0.2588 & & \\
\hline Sales index/100 & 8,402 & -0.9969 & 20.7184 & -6.2500 \\
\hline
\end{tabular}


Appendix C: Parameter estimation results: models w/ heterogeneity

\begin{tabular}{|c|c|c|c|c|}
\hline & \multicolumn{4}{|c|}{ Transition from... } \\
\hline & \multicolumn{2}{|c|}{ 'no' to 'no' } & \multicolumn{2}{|c|}{ 'no' to 'severe' } \\
\hline & \multicolumn{4}{|c|}{ base category: 'no' to 'medium' } \\
\hline & Coeff. & Std. err. & Coeff. & Std. err. \\
\hline 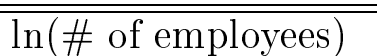 & $-0.2082^{*}$ & 0.1376 & -0.0932 & 0.2632 \\
\hline $\ln (\# \text { of employees })^{2}$ & -0.0022 & 0.0342 & -0.0579 & 0.0666 \\
\hline $\ln ($ age $)$ & $-0.5140^{* * *}$ & 0.1274 & $-0.5554^{* * *}$ & 0.2233 \\
\hline $\ln (\text { age })^{2}$ & 0.0481 & 0.0628 & $0.1861^{* *}$ & 0.1111 \\
\hline Sales index/100 & 0.1405 & 0.1204 & $-0.4185^{* *}$ & 0.2177 \\
\hline Limited liability & -0.0143 & 0.0568 & $0.7532^{* * *}$ & 0.1050 \\
\hline Diversification & 0.0010 & 0.0601 & $0.2798^{* * *}$ & 0.1026 \\
\hline Multiple creditors & $0.2171^{* *}$ & 0.1028 & -0.0279 & 0.1854 \\
\hline Corp. Shareholders & $0.1514^{*}$ & 0.0968 & 0.1412 & 0.1579 \\
\hline Constant & $4.5387^{* * *}$ & 0.1353 & $-0.7256^{* * *}$ & 0.2477 \\
\hline$\sigma_{21}$ & 0.0086 & 0.0978 & & \\
\hline$\sigma_{22}$ & 0.0667 & 0.1141 & & \\
\hline$\sigma_{23}$ & 0.1413 & 0.1713 & & \\
\hline \multicolumn{5}{|c|}{ \# of obs. and log-likelihood value } \\
\hline \# of obs. & 66,011 & & 686 & \\
\hline Total \# of obs. & 68,229 & & & \\
\hline Loglik. Value & $-11,009.50$ & & & \\
\hline
\end{tabular}


Transition from...

'medium' to 'no' 'medium' to 'severe'

base category: 'no' to 'medium'

\begin{tabular}{|c|c|c|c|c|}
\hline & \multicolumn{4}{|c|}{ base category: 'no' to 'medium' } \\
\hline & Coeff. & Std. err. & Coeff. & Std. err. \\
\hline$\overline{\ln (\# \text { of employees })}$ & $0.8241^{* * *}$ & 0.2472 & 0.1596 & 0.2033 \\
\hline $\ln (\# \text { of employees })^{2}$ & $-0.1424^{* * *}$ & 0.0603 & -0.0184 & 0.0516 \\
\hline $\ln ($ age $)$ & 0.1938 & 0.2134 & $0.3694^{* *}$ & 0.1845 \\
\hline $\ln (\text { age })^{2}$ & -0.1251 & 0.1115 & -0.0670 & 0.0915 \\
\hline Sales index/100 & $-0.2703^{*}$ & 0.2096 & $-0.4869^{* * *}$ & 0.1822 \\
\hline Limited liability & $0.3185^{* * *}$ & 0.0982 & $0.1222^{*}$ & 0.0814 \\
\hline Diversification & 0.0438 & 0.1017 & 0.0366 & 0.0860 \\
\hline Multiple creditors & $0.3437^{* * *}$ & 0.1406 & $-0.3285^{* * *}$ & 0.1484 \\
\hline Corp. Shareholders & $0.4115^{* * *}$ & 0.1666 & 0.0797 & 0.1647 \\
\hline Constant & $-3.7419^{* * *}$ & 0.2470 & $-2.7134^{* * *}$ & 0.1932 \\
\hline$\sigma_{21}$ & 0.1971 & 0.1947 & & \\
\hline$\sigma_{22}$ & 0.1121 & 0.1311 & & \\
\hline$\sigma_{23}$ & 0.0034 & 0.1721 & & \\
\hline \multicolumn{5}{|c|}{ \# of obs. and log-likelihood value } \\
\hline \# of obs. & 541 & & 798 & \\
\hline Total \# of obs. & 8,402 & & & \\
\hline Loglik. Value & $-4,529.61$ & & & \\
\hline
\end{tabular}


Appendix D: Parameter estimation results: models w/o heterogeneity

Transition from...

\begin{tabular}{|c|c|c|c|c|}
\hline & \multicolumn{2}{|c|}{ 'no' to 'no' } & \multicolumn{2}{|c|}{ 'no' to 'severe' } \\
\hline & \multicolumn{4}{|c|}{ base category: 'no' to 'medium' } \\
\hline & Coeff. & Std. err. & Coeff. & Std. err. \\
\hline $\ln$ (\# of employees) & $-0.2071^{*}$ & 0.1375 & -0.0905 & 0.2631 \\
\hline $\ln (\# \text { of employees })^{2}$ & -0.0025 & 0.0342 & -0.06 & 0.0666 \\
\hline $\ln ($ age $)$ & $-0.5135^{* * *}$ & 0.1273 & $-0.55^{* * *}$ & 0.2224 \\
\hline $\ln (\text { age })^{2}$ & 0.0479 & 0.0627 & $0.18^{* *}$ & 0.1108 \\
\hline Sales index/100 & 0.0014 & 0.0012 & $-0.0042^{* *}$ & 0.0022 \\
\hline Limited liability & -0.0142 & 0.0568 & $0.7533^{* * *}$ & 0.105 \\
\hline Diversification & 0.0012 & 0.0601 & $0.28^{* * *}$ & 0.1024 \\
\hline Multiple creditors & $0.2168^{* *}$ & 0.1028 & -0.0273 & 0.1845 \\
\hline Corp. Shareholders & $0.1510^{*}$ & 0.0967 & 0.1403 & 0.1577 \\
\hline Constant & $4.5353^{* * *}$ & 0.1352 & $-0.721^{* * *}$ & 0.2459 \\
\hline Firm size & $39.58^{* * *}$ & & $25.86^{* * *}$ & \\
\hline Firm age & $110.74^{* * *}$ & & $11.14^{* * *}$ & \\
\hline Coefficient vector & $148.20^{* * *}$ & & $89.97^{* * *}$ & \\
\hline Entire coeff. vector & $284.04^{* * *}$ & & & \\
\hline \multicolumn{5}{|c|}{ \# of obs. and log-likelihood value } \\
\hline \# of obs. & 66,011 & & 686 & \\
\hline Total \# of obs. & 68,229 & & & \\
\hline Loglik. Value & $-11,009.98$ & & & \\
\hline
\end{tabular}


Transition from...

'medium' to 'no' 'medium' to 'severe'

base category: 'no' to 'medium'

\begin{tabular}{lcrcr}
\hline \hline & \multicolumn{3}{c}{ base category: 'no' to 'medium' } \\
& Coeff. & Std. err. & Coeff. & Std. err. \\
\hline \hline $\ln ($ age $)$ & 0.1947 & 0.2124 & $0.3707^{* *}$ & 0.1842 \\
$\ln (\text { age })^{2}$ & -0.1263 & 0.1110 & -0.0680 & 0.0914 \\
$\ln (\#$ of employees $)$ & $0.8170^{* * *}$ & 0.2461 & 0.1592 & 0.2031 \\
$\ln (\# \text { of employees })^{2}$ & $-0.1410^{* * *}$ & 0.0600 & -0.0183 & 0.0516 \\
Limited liability & $0.3169^{* * *}$ & 0.0977 & $0.1213^{*}$ & 0.0813 \\
Corp. Shareholders & $0.4124^{* * *}$ & 0.1657 & 0.0795 & 0.1643 \\
Multiple creditors & $0.3428^{* * *}$ & 0.1401 & $-0.3306^{* * *}$ & 0.1481 \\
Diversification & 0.0432 & 0.1012 & 0.0359 & 0.0859 \\
Sales index/100 & $-0.0027^{*}$ & 0.0021 & $-0.0049^{* * *}$ & 0.0018 \\
Constant & $-3.7134^{* * *}$ & 0.2419 & $-2.7089^{* * *}$ & 0.1926
\end{tabular}

LR tests of joint significance $\left(\chi^{2}\right.$-values $)$

Firm size

$24.36^{* * *}$

3.48

Firm age

1.52

$18.12^{* * *}$

Coefficient vector

$76.61^{* * *}$

$44.23^{* * *}$

Entire coeff. vector

$118.09^{* * *}$

\# of obs. and log-likelihood value

\# of obs.

541

798

Total \# of obs.

8,402

Loglik. Value

$-4,530.50$ 


\section{References}

Agarwal, R. and Gort, M. (1996). The evolution of markets and entry, exit and the survival of firms. Review of Economics and Statistics 69, 567-574.

Almus, M., Engel, D., Prantl, S. (2000). The "Mannheim Foundation Panels" of the Centre for European Economic Research (ZEW). ZEW Dokumentation 00-22.

Altman, E.I. (1988). The prediction of coporate bankruptcy: a discriminant analysis, Garland.

Altman, E.I. (1984). The success of business failure prediction models: An international survey. Journal of Banking \& Finance 8, 171-198.

Altman, E.I., Kao, D.L. (1992). The implications of corporate bond rating drift. Financial Analysts Journal, 64-75.

Altman, E.I., Narayan, P. (1997). Business failure classification models: An international survey. In: Choi, F. (Ed.), International Accounting. Wiley.

Altman, E.I., Saunders, A. (1998). Credit risk measurement: Developments over the last 20 years. Journal of Banking \& Finance 21, 1721-1742.

Andrade, G., Kaplan, S.N. (1998). How costly is financial (not economic) distress? Evidence from highly leveraged transactions that became distressed. The Journal of Finance 53, 1443-1493.

Audretsch, D.B. (1991). New-firm survival and the technological regime. The Review of Economics and Statistics 73(3), 441-450.

Audretsch, D.B. (1995). Innovation and industry evolution. The MIT Press, Cambridge.

Audretsch, D.B., Mahmood, T. (1995). New firm survival: New results using a hazard function. The Review of Economics and Statistics 77(1), 97-103.

Audretsch, D.B., Vivarelli, M. (1993). New-firm start-ups in Italy. Centre for Economic Policy Research discussion paper 864.

Avery, R.B., Bostic, R.W., Calem, P.S., Canner, G.B. (1999). Consolidation and bank branching patterns. Journal of Banking \& Finance 23, 497-532.

Aw, B.Y., Batra, G. (1998). Firm size and the pattern of diversification. International Journal of Industrial Organization 16, 313-331.

Basel Committee on Banking Supervision (1999). A new capital adequacy framework. Basel Committee on Banking Supervision publication No. 50.

Basel Committee on Banking Supervision (2000). Range of practice in banks' internal ratings system. Basel Committee on Banking Supervision publication No. 66 .

Bates, T. (1990). Entrepreneur human capital inputs and small business longevity. The Review of Economics and Statistics 72(4), 551-559. 
Bennett, P. (1984). Applying portfolio theory to global bank lending. Journal of Banking \& Finance 8, 153-169.

Berger, P.G., Ofek, E. (1995). Diversification's effect on firms value. Journal of Financial Economics 37, 39-65.

Berger, A.N., Saunders, A., Scalise, J.M., Udell, G.F. (1998). The effects of bank mergers and acquisitions on small business lending. Journal of Financial Economics 50, 187229.

Berger, A.N., Udell, G.F. (1990). Collateral, loan quality, and bank risk. Journal of Monetary Economics 25, 21-42.

Berger, A.N., Udell, G.F. (1995). Relationship lending and lines of credit in small firm finance. Journal of Business 68(3), 351-381.

Besanko, D., Thakor, A.V. (1987). Competitive equilibrium in the credit market under asymmetric information. Jounral of Economic Theory 42, 167-182,

Bester, H. (1985). Screening vs. rationing in credit markets with imperfect information. American Economic Review 75(4), 850-855.

Bester, H. (1987). The role of collateral in credit markets with imperfect information. European Economic Review 31, 887-899.

Bester, H. (1994). The role of collateral in a model of debt renegotiation. Journal of Money, Credit and Banking 26(1), 72-86.

Bolton, P., Scharfstein, D.S. (1996). Optimal debt structure and the number of creditors. Journal of Political Economy 104(1), 1-25.

Boot, W., Thakor, A.V. (1994). Moral hazard and secured lending in an infinitely repeated credit market game. International Economic Review 35(4), 899-920.

Boot, W., Thakor, A.V., Udell, G.F. (1991). Secured lending and default risk: Equilibrium analysis, policy implications and empirical results. The Economic Journal 101, 458472.

Broll, U., Gilroy, M.B. (1986). Collateral in banking policy and adverse selection. The Manchester School 54(4), 357-366.

Brüderl, J., Preisendörfer, P., Ziegler, R. (1992). Survival chances of newly founded business organizations. American Sociological Review 57, 227-241.

Cantor, R., Packer, F. (1997). Differences of opinion and selection bias in the credit rating industry. Journal of Banking \& Finance 21, 1395-1417.

Caves (1998). Industry organization and new findings on the turnover and mobility of firms. Journal of Economic Literature 36, 1947-1982.

Chan, Y.-S., Kanatas, G. (1985). Asymmetric valuations and the role of collateral in loan agreements. Journal of Money, Credit and Banking 17(1), 84-95.

CIRET (1998). International business, investment and consumer surveys. CIRET office, Munich. 
Creditreform (2000). Insolvenzen in Europa, Neuss. (downloadable from the Internet at http: //www.creditreform.de/info/leistungen/

e_analysen/0007/index.hmtl)

Cressy, R. (1995). Pre-Entrepreneurial income, cash-flow growth and survival of startup businesses: Model and tests on U.K. data. Small Business Economics 8, 49-58.

Cressy, R. (1999). Why do most firms die young? Hull University Business School discussion paper.

D’Auria, C., Foglia, A., Reedtz, P.M. (1999). Bank interest rates and credit relationships in Italy. Journal of Banking \& Finance 23, 1067-1093.

del Angel, G.F., Márquez Diez-Canedo, J., Patino, G.E. (1998). A discrete Markov chain model for valuing loan portfolios. The case of Mexican loan sales, Journal of Banking \& Finance (22)10-11, 1457-1480.

Demigüç-Kunt, A., Maksimovic, V. (1996). Financial constraints, uses of funds, and firm growth: An international comparison. The World Bank Policy Research discussion paper 1671, Washington.

Detragiache, E., Garella, P.G., Guiso, L. (1997). Multiple versus single banking relationships. Paper presented at the conference on credit risk management and relationship banking Nov. 19-20, 1998, Center for Financial Studies, Frankfurt.

DeYoung, R., Goldberg, L.G., White, L.J. (1999). Youth, adoloscence, and maturity of bank: credit availability to small business in an era of banking consolidation. Journal of Banking \& Finance 23, 463-492.

Dun \& Bradstreet (1998). Business Failure Record, Murray Hill. (downloadable from the Internet at http://www.dnb.com/newsview/bfr96--97.pdf)

Egeln, J., Licht, G., Steil, F. (1997). Firm foundations and the role of financing constraints. Small Business Economics 9, 137-150.

Elsas, R., Krahnen, P. (1999). Collateral, default risk and relationship lending: An empirical study on financial contracting. Center for Financial Studies working paper.

Elston, J.A. (1996). Investment, liquidity constraints and bank relationships: Evidence from German manufacturing firms. CEPR discussion paper 1329.

Ericsson, R., Pakes, A. (1995). Markov-perfect industry dynamics: A framework for empirical work. Review of Economic Studies 62:1, 53-82.

Eurostat (2000). Services in Europe. Luxemburg.

Evans, D.S. (1987a). The relationship between firm growth, size and age: Estimates for 100 manufacturing industries. Journal of Industrial Economics 35, 567-581.

Evans, D.S. (1987b). Tests of alternatve theories of firm growth. Journal of Political Economy 95, 657-674.

Evans, D.S., Leighton, L.S. (1989). Some empirical aspects of entrepreneurship. The American Economic Review 79(3), 519-535. 
Ewert, R., Schenk, G., Szczesny, A. (2000). Determinants of bank lending performance in Germany. Schmalenbach Business Review 52, 344-362.

Freeman, J., Carroll, G.R., Hannan, M.T. (1983). The liability of newness: Age dependence in organizational death rates. American Sociological Review 48, 692-710.

Frank, M.Z. (1988). An intertemporal model of industry exit. Quartely Journal of Economics 103:2, 333-344.

Gilson, R.G. (1991). Unlimited liability and law firm organization: Tax factors and the directions of causation. Journal of Political Economy 99(2), 420-428.

Gordy, M.B. (2000). A comparative anatomy of credit risk models. Journal of Banking \& Finance 24, 119-149.

Gouriéroux, C. (1989). Econométrie des Variables Qualitatives. Economica, Paris.

Greene, W.H. (1997). Econometric analysis. Prentice-Hall, New York.

Grundfest, J.A. (1992). The limited future of unlimited liability: A capital market perspective. The Yale Law Journal 102(2), 387-425.

Hannan, M.T., Freeman, J. (1983). Niche width and the dynamics of organizational poulations. American Journal of Sociology 88, 1116-1145.

Harhoff, D. (1998). Are there Financing Constraints for Innovation and Investment in German Manufacturing Firms?, Annales d'Économie et de Statistique 49/50, 421456.

Harhoff, D., Körting, T. (1998). How many creditors does it take to tango? ZEW mimeo.

Harhoff, D., Stahl, K. (1995). Unternehmens- und Beschäftigungsdynamik in Westdeutschland: Zum Einfluß von Haftungsregeln und Eigentümerstrukturen. ifo-studies, 17-50.

Harhoff, D., Stahl, K., Woywode, M. (1996). Legal form, growth and exit of West German firms: Empirical results for manufacturing, trade and services industries. CEPR discussion paper 1401.

Harhoff, D., Stahl, K., Woywode, M. (1998). Legal form, growth and exit of West German firms: Empirical results for manufacturing, trade and services industries. Journal of Industrial Economics 46, 453-488.

Hausman, J.A., McFadden, D. (1984). Specification tests for the multinomial logit model. Econometrica 52(5), 1219-1240.

Hinz, T., Wilsdorf, S.H. (1999). Das Scheitern von Betriebsgründungen in den neuen Bundesländern. in Bögenhold, D., Schmidt, D. (Eds.): Eine neue Gründerzeit? Verlag Fakultas, Amsterdam.

Honjo, Y. (2000). Business failure of new firms: an empirical analysis using a multiplicative hazards model. International Journal of Industrial Organization 18, 557-574.

Horvath, M., Woywode, M. (1997). Entrepreneurs and the choice of limited liability. Stanford University discussion paper. 
Hubbard, R. (1999). Capital-market imperfections and investment. Journal of Economic Literature 36(March), 193-225.

Jayaratne, J., Wolken, J. (1999). How important are small banks to small business lending? New evidence from a survey of small firms. Journal of Banking \& Finance 23, 427-458.

Jovanovic, B. (1982). Selection and the evolution of industry. Econometrica 50(3), 649670.

Jovanovic, B. (1993). The diversification of production. Brookings Papers on Economic Activity: Microeconmics, 197-247.

Jovanovic, B. and MacDonald, G.M. (1994). The life cycle of a competitive industry. Journal of Political Economy 102(2), 322-347.

J.P. Morgan \& Co. (1997). Credit Metrics, New York.

Kaiser, U. , Kreuter, M., Niggemann, H. (2000). The ZEW/Creditreform Business Survey in the Business-related Services Sector: Sampling Frame, Stratification, Expansion and Results, ZEW discussion paper 00-22.

Kaiser, U., Voss, K. (2000). Do Business-Related Services Really Lag Behind Manufacturing in the Business Cycle?, ifo-studies 2/2000, 161-176.

Klepper (1996). Entry, exit, growth and innovation over the product life cycle. American Economic Review 86(3), 562-583.

Klepper and Simons (2000). The making of an oligopoly: Firm survival and technological change in the evolution of the U.S. tire industry. Journal of Political Economy 108(4), $728-760$.

Konings, J., Roodhooft, F., van der Gucht, L. (1996). The life cycle of firms and its impact on job creation and job destruction. Katholieke Universiteit Leuven working paper 9669.

Lang, L., Stulz, R. (1994). Tobin's q, corporate diversification, and firm performance. Journal of Political Economy 102(6), 1248-1280.

Lawrence, E.C., Smith, L.D., Rhoades, M. (1992). An analysis of default risk in mobile home credit. Journal of Banking \& Finance 17, 299-312.

Levensohn, A.R., Willard, K.L. (2000). Do firms get the financing they want? Measuring credit rationing experienced by small businesses in the U.S. Small Business Economics $14,83-94$.

Li, J., Guisinger, S. (1991). Comparative business failure of foreign-controlled firms in the United States. Journal of International Business Studies, 209-224.

Licht, G., Stahl, H. (1994). Enterprise panels on credit rating data, techniques and uses of enterprise panels. Proceedings of the first Eurostat international workshop on techniques of enterprise panels, 163-177.

McFadden, D. (1979). Quantitative methods for analysing travel behaviour of individuals: Some recent developments. In Hnesher, D., Stopher, P. (Eds): Behavioural travel modelling. Croom Helm, London. 
Mata, J. (1995). The survival of new plants: Start-up conditions and post-entry evolution. International Journal of Industrial Organization 13, 459-481.

Mattesini, F. (1990). Screening in the credit market: The role of collateral. European Journal of Political Economy 6, 1-22.

May-Strobl, E.-M., Paulini, M. (1996). Insolvenzen im Mittelstand: Daten und Fakten. IfM-Materialien 121.

Miles, I. (1993). Services in the New Industrial Economy. Futures. July/August 1993, 653-672.

Nguyen van, P., Kaiser, U., Lainey, F. (2000). The performance of German firms in the business-related services sector: a dynamic analysis. ZEW discussion paper 00-38.

Nickell, P., Perraudin, W., Varotto, S. (2000). Stability of rating transition. Journal of Banking \& Finance 24, 203-227.

Pakes, A. (1998). Empirical implications of alternative models of firm dynamics. Journal of Economic Theory 79, 1-45.

Petersen, M.A., Rajan, R.G. (1994). The effect of credit market competition on lending relationships. Quarterly Journal of Economics 110, 405-443.

Philips, B.D., Kirchhoff, B.A. (1989). Formation, growth and survival; Small firm dynamics in the U.S. economy. Small Business Economics 1, 65-74.

Plötscher, C., Rottmann, H. (1998). Investment behaviour and financing constraints in German manufacturing firms: A bivariate probit analysis. ifo Diskussionsbeiträge 53, München.

Prantl, S. (2000). Post-entry selection among newly founded firms in East and West Germany after unification. University of Mannheim discussion paper.

Schmidt-Mohr, U. (1997). Rationing versus collaterization in competitive and monopolistic credit markets with asymmetric information. European Economic Review 41, 13211342 .

Sharma, A. (1998). Mode of entry and ex-post performance. Strategic Management Journal 19, 879-900.

Sharpe, S.A. (1990). Asymmetric information, bank lending, and implicit contract: A stylized model of customer relationships. Journal of Finance 45, 1069-1087.

Sleuwaegen, L. Dehandschutter, W. (1997). Entry and exit in Belgian manufacturing. in Geroski, P.A., Schwalbach, J. (Eds): Entry and market contestability. Blackwell, Oxford.

Small, K., Hsiao, C. (1985). Multinomial logit specification tests. International Economic Review 26(3), 619-627.

Smith, L.D., Lawrence, E.C. (1995). Forecasting losses on a liquidating long-term loan porfolio. Journal of Banking \& Finance 19, 959-985. 
Somerville, R.A., Tafller, R.J. (1995). Banker judgement versus formal forecasting models: The case of country risk assessment. Journal of Banking \& Finance 19, 281-297.

Stahl, K. (1991). Das Mannheimer Unternehmenspanel: Konzept und Entwicklung. Mitteilungen zur Arbeitsmarkt- und Berufsforschung 4/91, 735-738.

Statistisches Bundesamt (1997). Kostenstruktur der Unternehmen der Wirtschafts- und Unternehmensberatung sowie der Heilpraktikerpraxen. Stuttgart, Metzler-Poeschl.

Statistisches Bundesamt (1998a). Kostenstruktur bei Rechtsanwälten und Notaren, bei Wirtschaftsprüfern, vereidigten Buchprüfern, Steuerberatern und Steuerbevollmächtigten, bei Architekten und beratenden Ingenieuren 1995. Stuttgart, Metzler-Poeschl.

Statistisches Bundesamt (1998b). Kostenstruktur des gewerblichen Güterkraftverkehrs, der Speditionen und Lagereien, der Binnenschiffahrt (Güterbeförderung und der Seeund Küstenschiffahrt 1995. Stuttgart, Metzler-Poeschl.

Statistisches Bundesamt (1998c). Finanzen und Steuern, Fachserie 14, Reihe 8, Umsatzsteuer 1996. Stuttgart, Metzler-Poeschl.

Statistisches Bundesamt (2000). Finanzen und Steuern, Fachserie 14, Reihe 8, Umsatzsteuer 1998. Stuttgart, Metzler-Poeschl.

Stiglitz, J.E., Weiss, A. (1981). Credit rationing in markets with imperfect information. American Economic Review 71(3), 393-410.

Strahan, P.E., Weston, J. (1996). Small business lending and bank consolidation: Is there cause for concern? Current issues in Economics and Finance 2(3), 1-5.

Taylor, M.P. (1999). Survivall of the fittest? An analysis of self-employment duration in Britain. The Economic Journal 109(March), C140-C155.

Treacy, W.F., Carey, M. (2000). Credit risk rating systems at large US banks. Journal of Banking \& Finance 24, 167-201.

Westhead, P., Storey, D.J. (1997). Financial constraints on the growth of high technology small firms in the United Kingdom. Applied Financial Economics 7, 197-201.

Wette, H.C. (1983). Collateral in credit rationing in markets with imperfect information: Note. American Economic Review 73(3), 442-445.

Wilner, B.S. (2000). The exploitation of relationships in financial distress: The case of trade credit. The Journal of Finance 55, 153-178.

Winker, P. (1999). Causes and effects of financing constraints at the firm level. Small Business Economics 12, 169-181.

Wu, H.-K. (1969). Bank examiner criticisms, bank loan defaults, and bank loan quality. Journal of Finance 24, 697-705.

Wuffli, P.A., Hunt, D.A. (1993). Fixing the credit problem. The McKinsey Quarterly 2/1993, pp. 93-106. (downloadable from the Internet at http: //mckinseyquarterly.com/article_page.asp?articlenum=869 